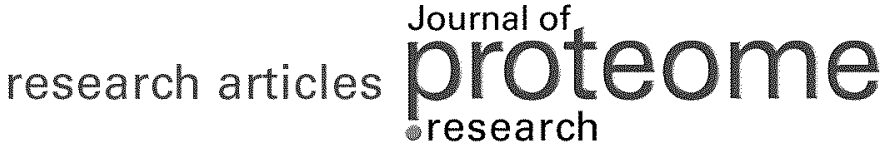

\section{Proteomics Analysis of Kojic Acid Treated A375 Human Malignant Melanoma Cells}

\author{
Jiraporn Nawarak, ${ }^{\dagger}$ Rosa Huang-Liu, ${ }^{\ddagger}$ Shao-Hsuan Kao, ${ }^{\S}$ Hsien-Hua Liao," \\ Supachok Sinchaikul, ${ }^{\dagger}$ Shui-Tein Chen, ${ }^{\dagger, \perp}$ and Sun-Long Cheng*,ll \\ Institute of Biological Chemistry and Genomics Research Center, Academia Sinica, Taipei, Taiwan, School of \\ Nutrition, Chung Shan Medical University, Taichung, Taiwan, Institute of Biochemistry and Biotechnology, \\ Chung Shan Medical University, Taichung, Taiwan, Department of Plastic Surgery, Chung Shan Medical \\ University, Chung Shan Medical University Hospital, Taichung, Taiwan, and Institute of Biochemical Sciences, \\ College of Life Science, National Taiwan University, Taipei, Taiwan
}

Received December 21, 2007

\begin{abstract}
Although the toxicogenomics of kojic acid treated A375 human malignant melanoma cells has been elucidated, the proteomics of cellular response is still poorly understood. We performed proteomic analysis to investigate the anticancer effect of kojic acid on protein expression profile in A375 cells. A375 cells were treated with kojic acid at $8 \mu \mathrm{g} / \mathrm{mL}$ for 24,48 , and $72 \mathrm{~h}$. With the use of 2-D PAGE and MALDI-Q-TOF MS and MS/MS analyses, proteomic profiles of A375 cells between control and kojic acid treatment were compared, and 30 differentially expressed proteins, containing 2 up-regulated proteins and 28 down-regulated proteins, were identified. Among these proteins, 17 isoforms of 5 identical proteins were observed and 11 chaperone proteins showed the high proportion of protein spots with $36.7 \%$ of total proteins. Bioinformatic tools were used to search for protein function and prediction of protein interaction. Sixteen differentially expressed proteins exhibited interaction network linked to the downstream regulations of p53 tumor suppressor and cell apoptosis, which may lead to suppress the melanogenesis and tumorigenesis of kojic acid treated A375 cells. In addition, GRP75, VIME and 2AAA were validated by Western blot analysis, whereas GRP75, 2AAA, HS90B, ENPL and KPYM were validated by RT-PCR. Therefore, these proteins play the important roles in cancer progression and may be potential biomarkers that are useful for diagnostic and therapeutic applications of malignant melanoma cancer.
\end{abstract}

Keywords: kojic acid • A375 cells • malignant melanoma • proteomics • cancer

\section{Introduction}

Kojic acid (5-hydroxy-2-hydroxymethyl-1,4-pyrone) is a secondary metabolic product and widely used as a food additive for preventing enzymatic discoloration of vegetable, crabs and shrimps $^{1,2}$ and as a skin lightening or bleaching agent in cosmetic preparations. ${ }^{3,4}$ Although the reported safety aspects of kojic acid used in food additive and cosmetics have shown no human health risk, ${ }^{3}$ there are some reports which have shown the evaluation of the tumorigenic potential of kojic acid and its genotoxic effects in several in vitro tests, including mutation in Salmonella typhimurium strains TA98, TA100 and

\footnotetext{
* To whom correspondence should be addressed. Dr. Sun-Long Cheng, M.D., Department of Plastic Surgery, Chung Shan Medical University, Chung Shan Medical University Hospital, Taichung, 40242, Taiwan. Tel, +886-424719933; e-mail, chuangsl@ms57.hinet.net.

${ }^{\dagger}$ Institute of Biological Chemistry and Genomics Research Center, Academia Sinica.

₹ School of Nutrition, Chung Shan Medical University.

${ }^{\S}$ Institute of Biochemistry and Biotechnology, Chung Shan Medical University.

"Department of Plastic Surgery, Chung Shan Medical University, Chung Shan Medical University Hospital.

${ }^{\perp}$ Institute of Biochemical Sciences, College of Life Science, National Taiwan University.
}

TA1535, and sister chromatid exchanges and chromosome aberrations test in Chinese hamster ovary $(\mathrm{CHO})$ cells. $^{5-7}$ Chronic oral administration of kojic acid has been reported to produce thyroid adenomas in mice and rats. ${ }^{8,9}$ In contrast to in vivo studies, genotoxic activity of kojic acid was negative. The genotoxicity and carcinogenicity in rat liver and the photogenotoxicity and carcinogenicity in mouse skin were not found. ${ }^{10}$ After kojic acid administration in drinking water, the tumor initiation activity was not found in the rat thyroid. ${ }^{11}$ As a skin lightening agent, the frequency of sensitization of skin care containing kojic acid was studied in female patients with suspected cosmetic-related contact dermatitis. It is considered to have high sensitizing potential, as a comparatively high frequency of contact sensitivity was observed. ${ }^{12}$ The topical use of kojic acid as a skin lightening agent also resulted in minimal exposure but it has negligible risk of genotoxicity or toxicity in humans. ${ }^{13}$ Although the tumorigenic potential and some genotoxic effect of kojic acid on human skin cell lines has been widely studied, the effect of kojic acid on protein expression level that mostly possesses many biological functions on human skin has never been reported. 


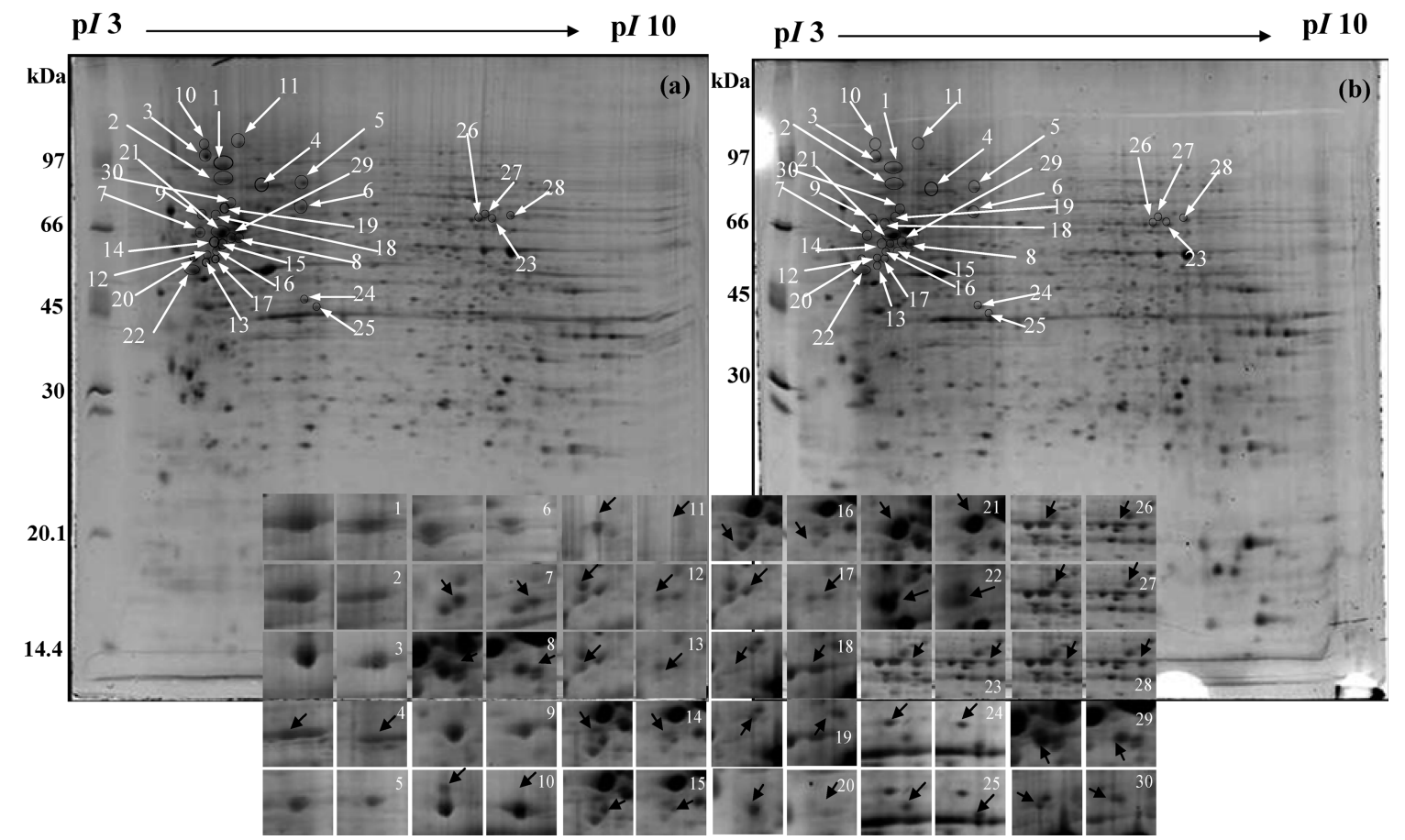

Figure 1. 2-D PAGE images of A375 human malignant melanoma cells between control (a) and $72 \mathrm{~h}$ treatment (b). The images in the panels are the regions showing differentially expressed spots for protein identification. The pointed arrows indicate the identified protein spots in this study.

In this study, we used 2-D PAGE to investigate the biological effects of kojic acid on the protein expression of A375 human malignant melanoma cells through its effect on melanocytic tumorigenesis for cancer therapy and other related side effects. In addition, the bioinformatics tools were used to search the protein ontology, category classification, according to cellular component, molecular function and biological process, and prediction of protein interaction network in order to understand the cellular response and regulatory mechanism in the protein expression level of human skin cancer cells.

\section{Materials and Methods}

Test Substances and Chemicals. Human malignant melanoma cell line A375 (CRL-1619) was obtained from ATCC (Rockville, MD). Fetal bovine serum (FBS), sodium pyruvate, antibiotic-antimycotic and TRIzol reagent were purchased from Invitrogen (Carlsbad, CA). Dulbecco's Modified Eagle's Medium (DMEM), DPBS and Trypsin-EDTA were purchased from Atlanta Biologicals (Norcross, GA). RNeasy Mini Kit was purchased from Qiagen (Valencia, CA). Kojic acid and sodium bicarbonate were purchased from Sigma (St. Louis, MO). Immobiline DryStrips (IPG strips), carrier ampholytes (IPG buffers), ammonium persulfate and TEMED were purchased from GE Healthcare (Björkgatan, Uppsala, Sweden). Urea and CHAPS were purchased from J.T. Baker (Phillipsburg, NJ). Iodoacetamide and glutaraldehyde were purchased from Fluka (Industriestrasse, Buchs, Switzerland). Dithioerythritol (DTE) was purchased from AppliChem (Darmstadt, Germany). SYPRO Ruby was purchased from Molecular Probes (Eugene, OR). All primary and secondary antibodies were purchased from Abcam, Inc. (Cambridge, CA).

Cell Culture and Sample Preparation. A375 human malignant melanoma cells were used in this study. The conditions of cell culture and treatment were the same as our previous report. ${ }^{14}$ Briefly, the cells were treated with kojic acid at $8 \mu \mathrm{g} /$
$\mathrm{mL}$ for 24,48 , and $72 \mathrm{~h}$. The experiment of kojic acid treatment was done in triplicate.

Two-Dimensional Polyacrylamide Gel Electrophoresis (2-D PAGE). A375 cells were resuspended in $350 \mu \mathrm{L}$ of a lysis buffer containing $7 \mathrm{M}$ Urea, 4\% CHAPS, 2 M Thiourea, $65 \mathrm{mM}$ DTE and $0.5 \%$ IPG buffer pH 3-10NL. For the first dimensional isoelectric focusing (IEF), the protein solutions (150 $\mu$ g protein) were rehydrated overnight with the commercial IPG strips (GE Healthcare, $18 \mathrm{~cm}, \mathrm{pH} 3-10 \mathrm{NL}$ ). Subsequently, isoelectric focusing (IEF) was carried out for $70 \mathrm{kVh}$ using IPGphor IEF system (GE Healthcare) at $20{ }^{\circ} \mathrm{C}$ following the manufacturer's instruction. Prior to the second dimension, the IPG strips were equilibrated by two equilibration steps. ${ }^{15}$ The strips were loaded and run on $12.5 \%$ polyacrylamide slab gel $\left(18 \times 18 \mathrm{~cm}^{2}\right)$ using the Protean II xi Cell system (Bio-Rad) with a programmable power control, at $45 \mathrm{~mA} /$ gel at $15{ }^{\circ} \mathrm{C}$ until the dye front reached the gel bottom. The separated proteins were visualized with SYPRO Ruby dye. The 2-D gel images were scanned using a Typhoon 9200 laser scanner (GE Healthcare) and exported to the image analysis software program, using PDQuest software package version 7.1.1 (Bio-Rad). Changes in fold expression of proteins were compared between control and $72 \mathrm{~h}$ of kojic acid treatment.

In-Gel Tryptic Digestion. The differentially expressed protein spots were excised from 2-D gels and digested with trypsin as previously reported. ${ }^{15}$ Peptides were extracted twice with 50 $\mu \mathrm{L}$ of $50 \%$ acetonitrile (ACN) $/ 5 \%$ trifluoroacetic acid (TFA); the extracted solutions were then combined and dried with a Speed-Vac concentrator. The peptide pellets were resuspended with $10 \mu \mathrm{L}$ of $0.1 \%$ TFA and purified using ZipTipC18 (Millipore, Bedford, MA). The peptides were finally eluted with $5 \mu \mathrm{L}$ of $75 \%$ ACN $/ 0.1 \%$ formic acid.

Mass Spectrometric Analysis. The trypsinized samples were premixed in a ratio of $1: 1$ with the matrix solution $(5 \mathrm{mg} / \mathrm{mL}$ $\alpha$-cyano-4-hydroxycinnamic acid (CHCA) in 50\% ACN, 0.1\% (v/ 


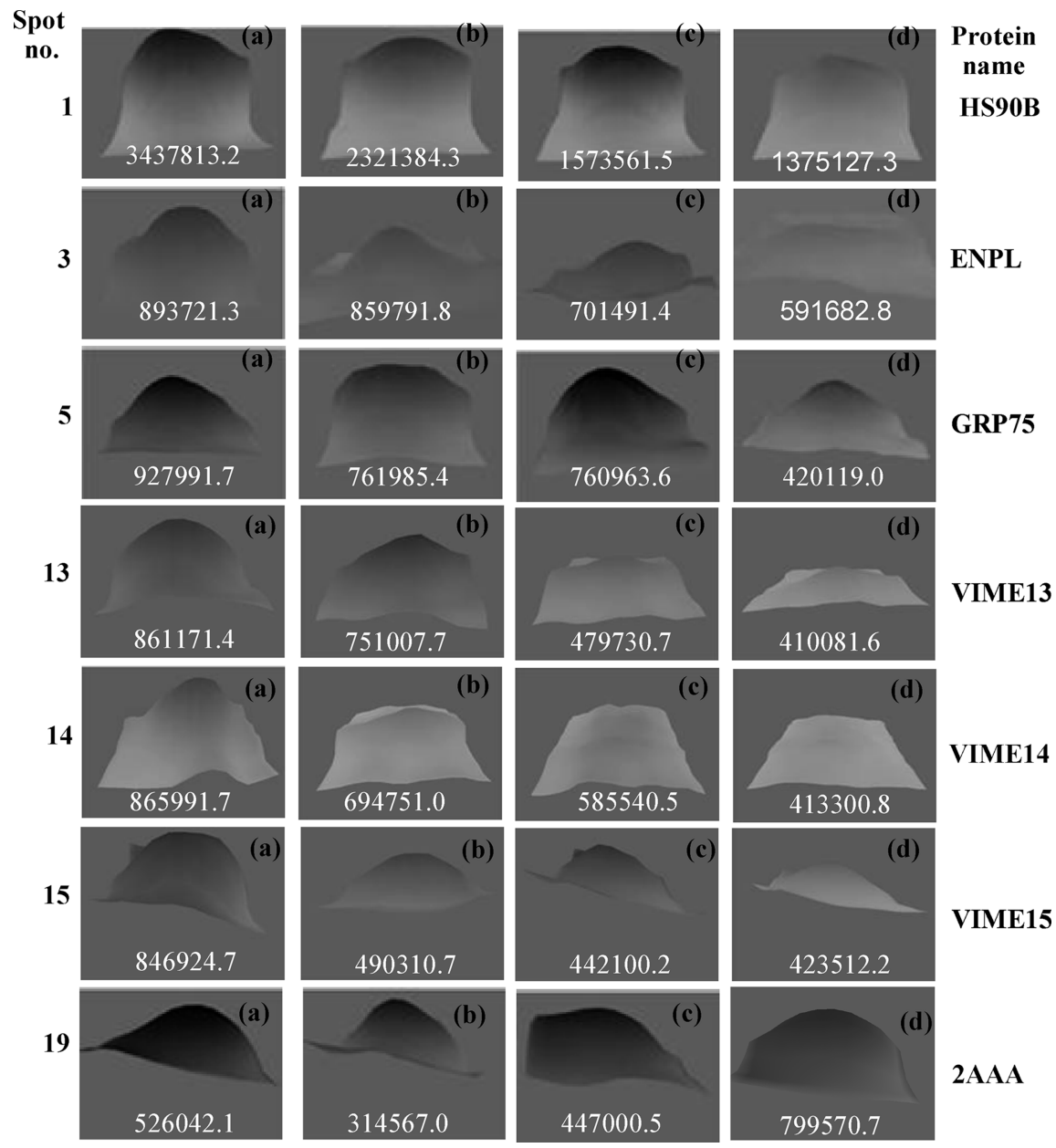

Figure 2. 3-D views of some protein spots obtained from the experiment. These proteins were found to be correlated with p53 or involved with tumor biology. Labels: (a) control, (b) $24 \mathrm{~h}$ treatment, (c) $48 \mathrm{~h}$ treatment and (d) $72 \mathrm{~h}$ treatment. The protein names according to spot number are HS90B, ENPL, GRP75, VIME (nos.13, 14, 15) and 2AAA (no. 19). Intensities of the 3-D spots were analyzed by PDQuest software package version 7.1.1.

v) TFA and $2 \%(\mathrm{w} / \mathrm{v})$ ammonium citrate) and spotted onto the 96-well MALDI sample stage. The samples were analyzed by the Q-TOF Ultima MALDI instrument (M@LDI; Micromass, Manchester, U.K.), as described previously. ${ }^{15}$ The MASCOT (http://www.matrixscience.com) search engine was used for peptide mass fingerprinting (PMF) and MS/MS ions search. Search parameters were monoisotopic mass, oxidized at methionine residues and carbamidomethylated at cysteine residues. Only one missed trypsin cleavage was allowed, and peptide mass tolerances of $50 \mathrm{ppm}$ were used for PMF and MS/ MS ions search. The search of identified proteins was performed using the Swiss-Prot database.

Reverse Transcriptase-Polymerase Chain Reaction (RT-PCR). After A375 cells treated with kojic acid at 24, 48 and $72 \mathrm{~h}$ were collected, total RNA was extracted by a modified method using TRIzol reagent combined with RNeasy Mini Kit, according to the manufacturer's instruction. The total RNA was quantified by the NanoDrop ND-1000 UV-vis Spectrophotometer (Thermo Fisher Scientific, Wilmington, DE). The sequences of primers used were (1) HS90B, forward 5'-GGTGGTGCTGCTGTTTGAAA-3' and reverse 5'-AACTGCAGCATTGGGTTCCT-3'; (2) ENPL, forward 5'-ATGGAGATCCTGGAATAGGCA- $3^{\prime}$ and reverse 5'-GCTTTTCTCCAATCAAATGGC-3'; (3) GRP75, forward 5'-CGACACAGAAACCAAGATGGAA- ${ }^{\prime}$ and reverse $5^{\prime}$-AAGAGAGGATGCTGCCTGTCTAA-3'; (4) pyruvate kinase M2, forward 5'-GAAGCCT-
GTCATCTGTGCTACTCA-3' and reverse 5'-AGGATAGTCCCCTTTGGCTGTT-3'; (5) 2AAA, forward 5'-ATGCTACCCACGGTTCTGC- $3^{\prime}$ and reverse $5^{\prime}$-ACAGAACAGTCAGAGCCTCCT-3'. PCR was carried out with a Px2 Thermal Cycler (Thermo Fisher Scientific, CA). The PCR condition was to heat at $95^{\circ} \mathrm{C}$ for $1 \mathrm{~min}$, followed by denaturation at $95{ }^{\circ} \mathrm{C}$ for $1 \mathrm{~min}$, annealing at $52-55$ ${ }^{\circ} \mathrm{C}$ for $45 \mathrm{~s}$, extension at $72{ }^{\circ} \mathrm{C}$ for $1 \mathrm{~min}$ for 25 cycles, and finally incubation at $72{ }^{\circ} \mathrm{C}$ for $10 \mathrm{~min}$. The PCR products were analyzed on $1.5 \%$ agarose gel.

Western Blotting. After SDS-PAGE analysis of control and treated samples under reducing conditions, the proteins on gel were electroblotted onto PVDF membrane using a semidry apparatus (GE Healthcare). The PVDF membrane was reacted with anti-human GRP75, 2AAA, or VIME monoclonal antibodies (Abcam; dilution 1:2000) as the primary antibody and with HRP-conjugated monoclonal anti-mouse IgG antibody (Abcam; dilution 1:2000) as the secondary antibody. $\beta$-Actin was used as control protein (dilution 1:3000). Reactive protein bands were then visualized by enhanced chemiluminescence Western blotting detection system using ECL Kit (GE Healthcare). Western blot analysis of each protein was duplicated.

Statistical Analysis. Analysis of proteins regulation changed upon kojic acid treatment was done on three independent experiments. Each set of 2-D PAGE gels was compared by image comparison software separately. The thresholds of up- 
Table 1. Protein Identification of Differentially Expressed Proteins in Kojic Acid Treated A375 Cells by MALDI-TOF MS and MS/MS

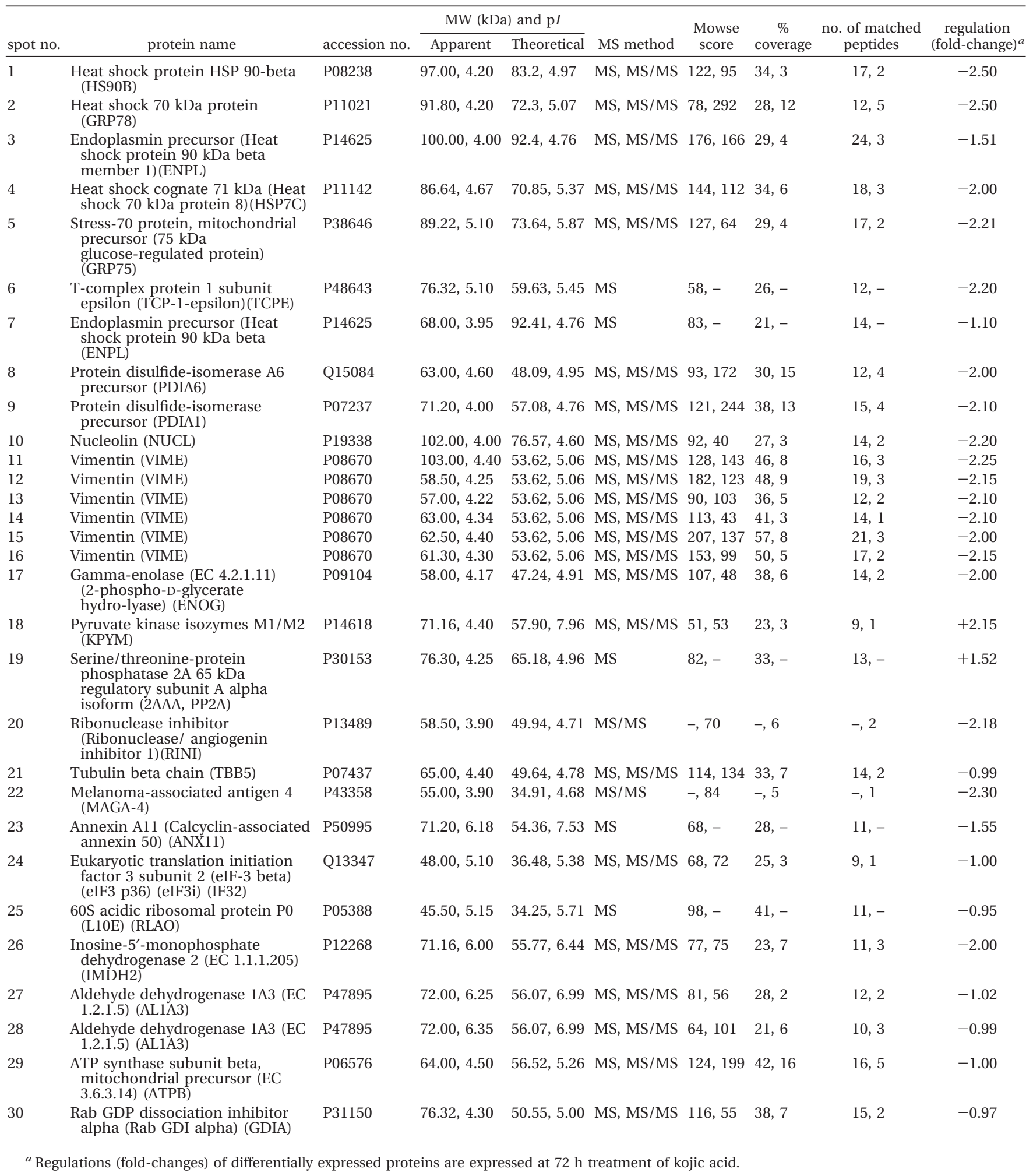

regulated proteins and down-regulated proteins were 1.5- and 0.9 -fold changes, respectively. Differentially expressed protein spots, which were found in all sets of experiment, in particular in comparison to $72 \mathrm{~h}$ treatment, were selected for protein identification.

Bioinformatics Tools for Protein Searches. For the bioinformatics tools to search protein ontology, we used the combination of databases to gain information on protein annotation (name, accession number and symbol), family and superfamily clusters, similar protein, protein encoded gene, category classifications of cellular component, molecular function and biological process, and references. The protein search programs were used the following sequential order of databases: NCBI (http://www.ncbi.nlm.nih.gov), Swiss-Prot/TrEMBL (http://www.expasy.ch/sprot) and Proteome (http://www.proteom.com/databases/HumanPD/reports). In addition, the functional protein association networks or protein interactions were searched by STRING database (http://string.embl.de/). 
Table 2. Category Classification of Differentially Expressed Proteins in Kojic Acid Treated A375 Cells and Their Interaction Partners

\begin{tabular}{|c|c|c|c|c|c|}
\hline $\begin{array}{l}\text { spot } \\
\text { no. }\end{array}$ & protein name & cellular component & molecular function & biological process & $\begin{array}{l}\text { predicted protein } \\
\text { interaction partners }\end{array}$ \\
\hline 1 & $\begin{array}{l}\text { Heat shock protein HSP } \\
\text { 90-beta (HS90B) }\end{array}$ & $\begin{array}{l}\bullet \text { cytoplasm } \\
\bullet \text { melanosome stage } 1-4\end{array}$ & $\begin{array}{l}\text { •nitric-oxide synthase } \\
\text { regulator activity } \\
\text {-TPR domain binding }\end{array}$ & $\begin{array}{l}\text {-positive regulation of } \\
\text { nitric oxide } \\
\text { biosynthetic process } \\
\text {-response to unfolded } \\
\text { protein }\end{array}$ & •TP53/p53 \\
\hline 2 & $\begin{array}{l}\text { Heat shock } 70 \mathrm{kDa} \\
\text { protein (GRP78) }\end{array}$ & $\begin{array}{l}\text { •cell surface } \\
\text { •endoplasmic reticulum } \\
\text { lumen } \\
\text {-ER-Golgi intermediate } \\
\text { compartment } \\
\text { •membrane } \\
\text { •nucleus } \\
\text {-perinuclear } \\
\text { •cytoplasm } \\
\text { •melanosome stage } 1-4\end{array}$ & $\begin{array}{l}\text {-ATP binding } \\
\text { •calcium ion binding } \\
\text { •caspase inhibitor } \\
\text { activity } \\
\text { •protein binding, } \\
\text { bridging } \\
\text { •unfolded protein } \\
\text { binding }\end{array}$ & - anti-apoptosis & $\begin{array}{l}\bullet \text { ENPL } \\
\bullet \text { PDIA6 } \\
\bullet \text { GRP75 } \\
\bullet p 53\end{array}$ \\
\hline 3,7 & $\begin{array}{l}\text { Heat shock protein } 90 \\
\text { kDa beta member } \\
\text { 1(ENPL) }\end{array}$ & $\begin{array}{l}\bullet \text { cytosol } \\
\bullet \text { microsome } \\
\bullet \text { endoplasmic reticulum } \\
\text { lumen and membrane } \\
\text { •perinuclear region of } \\
\text { cytoplasm } \\
\text { cytoplasm } \\
\text {-melanosome stage } 1-4\end{array}$ & $\begin{array}{l}\text { •calcium ion binding } \\
\text {-low-density lipoprotein } \\
\text {-receptor binding } \\
\text { - RNA binding } \\
\text { •virion binding }\end{array}$ & $\begin{array}{l}\text {-anti-apoptosis } \\
\text {-protein transport } \\
\text {-response to hypoxia } \\
\text {-sequestering of } \\
\text { calcium ion }\end{array}$ & $\begin{array}{l}\cdot \mathrm{GRP} 75 \\
\cdot \text { GRP78・PDIA4 } \\
\cdot \text { receptor } \\
\text { tyrosinase-protein } \\
\text { kinase erbB-2 }\end{array}$ \\
\hline 4 & $\begin{array}{l}\text { Heat shock cognate } \\
71 \mathrm{kDa}(\text { HSP7C) }\end{array}$ & $\begin{array}{l}\text { •cell surface } \\
\text { •intracellular } \\
\text { •melanosome stage } 1-4\end{array}$ & $\begin{array}{l}\text {-ATPase activity } \\
\text { •protein binding }\end{array}$ & $\begin{array}{l}\text { •protein folding, } \\
\text { response to unfolded } \\
\text { protein }\end{array}$ & $\begin{array}{l}\bullet \text { Bcl-2 binding } \\
\text { athanogene-1, -3 } \\
\cdot \text { HSP86 } \\
\cdot \text { HSP60 }\end{array}$ \\
\hline 5 & $\begin{array}{l}\text { Stress-70 protein, } \\
\text { mitochondrial } \\
\text { precursor (GRP75) }\end{array}$ & $\begin{array}{l}\text { •cell surface } \\
\bullet \text { mitochondrion }\end{array}$ & $\begin{array}{l}\text { •unfolded protein } \\
\text { binding }\end{array}$ & -antiapoptosis & $\begin{array}{l}\bullet \text { p53 } \\
\text {-DnaJ homologue } \\
\text { subfamily A and B } \\
\text { members } \\
\text { •HSP90B1 }\end{array}$ \\
\hline 6 & $\begin{array}{l}\text { T-complex protein } 1 \\
\text { subunit epsilon } \\
\text { (TCP-1-epsilon) } \\
\text { (TCPE) }\end{array}$ & •cytoplasm & •protein binding & $\begin{array}{l}\text {-protein folding } \\
\text { •mammalian cell cycle } \\
\text { progression } \\
\text { •cell mobility }\end{array}$ & $\begin{array}{l}\text {-T-complex protein } 1 \\
\text { different subunits } \\
\text { •Beta-Actin }\end{array}$ \\
\hline 8 & $\begin{array}{l}\text { Protein } \\
\text { disulfide-isomerase A6 } \\
\text { precursor (PDIA6) }\end{array}$ & $\begin{array}{l}\text { •endoplasmic } \\
\text { reticulum } \\
\text {-ER-Golgi intermediate } \\
\text { compartment } \\
\text { •melanosome stage } 1-4\end{array}$ & $\begin{array}{l}\text { •protein binding } \\
\text { •protein disulfide } \\
\text { isomerase activity }\end{array}$ & $\bullet$ protein folding & $\begin{array}{l}\text {-ERp31 } \\
\text { - GRP78 }\end{array}$ \\
\hline 9 & $\begin{array}{l}\text { Protein } \\
\text { disulfide-isomerase } \\
\text { precursor (PDIA1) }\end{array}$ & $\begin{array}{l}\text { •cell surface } \\
\text { •endoplasmic reticulum } \\
\text { •ER-Golgi intermediate } \\
\text { compartment } \\
\text { •extracellular region }\end{array}$ & $\begin{array}{l}\text {-procollagen-proline } \\
\text { 4-dioxygenase activity } \\
\text {-protein binding } \\
\text { •protein disulfide } \\
\text { isomerase activity }\end{array}$ & $\begin{array}{l}\text { •peptidyl-proline } \\
\text { hydroxylation to } \\
\text { 4-hydroxy-L-proline }\end{array}$ & $\begin{array}{l}\bullet \text { ERp31 } \\
\bullet \text { GRP78 }\end{array}$ \\
\hline 10 & Nucleolin (NUCL) & $\begin{array}{l}\bullet \text { cell cortex } \\
\bullet \text { nucleolus }\end{array}$ & $\begin{array}{l}\text { •protein C-terminus } \\
\text { binding } \\
\text { •RNA binding }\end{array}$ & •angiogenesis & $\begin{array}{l}\cdot \text { DNA topoisomerase } \\
\text { •p53 } \\
\text { •proliferation-associated } \\
\text { protein 2G4 }\end{array}$ \\
\hline $\begin{array}{l}11,12,13 \\
14,15,16\end{array}$ & Vimentin (VIME) & $\begin{array}{l}\bullet \text { cytoplasm•intermediate } \\
\text { filament }\end{array}$ & $\begin{array}{l}\text { •protein binding } \\
\text { •structural constituent } \\
\text { of cytoskeleton }\end{array}$ & •cell motility & $\begin{array}{l}\text {-RAF-1 } \\
\text {-proteosome subunit } \\
\text { alpha type1 } \\
\text { •protein kinase N1 }\end{array}$ \\
\hline 17 & Gamma-enolase(ENOG) & •cytoplasm & $\begin{array}{l}\bullet \text { phosphopyruvate } \\
\text { hydratase activity }\end{array}$ & •glycolysis & $\begin{array}{l}\text {-pyruvate kinase } \\
\text { isoenzyme M1/M2 } \\
\text { •enzymes in glycolytic } \\
\text { pathway }\end{array}$ \\
\hline 18 & $\begin{array}{l}\text { Pyruvate kinase } \\
\text { isozymes M1/M2 } \\
\text { (KPYM) }\end{array}$ & •cytoplasm & $\begin{array}{l}\text {-protein binding } \\
\text { pyruvate kinase } \\
\text { activity }\end{array}$ & $\begin{array}{l}\bullet \text { glycolysis } \\
\bullet \text { cell proliferation }\end{array}$ & $\begin{array}{l}\text {-alpha enolase } \\
\text { - beta enolase } \\
\text { •pyruvate } \\
\text { dehydrogenase E1 } \\
\text { subunits }\end{array}$ \\
\hline 19 & $\begin{array}{l}\text { Serine/ } \\
\text { threonine-protein } \\
\text { phosphatase 2A } \\
(2 \mathrm{AAA}, \mathrm{PP} 2 \mathrm{~A})\end{array}$ & $\begin{array}{l}\bullet \text { cytoplasm } \\
\bullet \text { membrane } \\
\bullet \text { microtubule } \\
\bullet \text { cytoskeleton, } \\
\bullet \text { mitochondrion } \\
\bullet \text { nucleus } \\
\text { •protein phosphatase } \\
\text { type 2A complex }\end{array}$ & $\begin{array}{l}\text { •antigen binding, } \\
\bullet \text { protein } \\
\text { heterodimerization } \\
\text { activity } \\
\text { •protein phosphatase } \\
\text { type } 2 \mathrm{~A} \text { regulator } \\
\text { activity }\end{array}$ & $\begin{array}{l}\text { •ceramide metabolic } \\
\text { process } \\
\text { •inactivation of MAPK } \\
\text { activity } \\
\text { •induction of apoptosis } \\
\text { •negative regulation of } \\
\text { cell growth } \\
\text {-regulation of cell } \\
\text { adhesion } \\
\text {-regulation of cell } \\
\text { differentiation } \\
\text {-regulation of } \\
\text { progression through } \\
\text { cell cycle } \\
\text {-regulation of } \\
\text { transcription } \\
\text {-second-messenger- } \\
\text { mediated signaling } \\
\text { •response to organic } \\
\text { substance }\end{array}$ & $\begin{array}{l}\text {-RAF proto-oncogene } \\
\text { serine/threonine } \\
\text { kinase } \\
\text {-serine/threonine } \\
\text { protein phosphatase } \\
\text { isoforms } \\
\text {-protein KIAA0889 }\end{array}$ \\
\hline
\end{tabular}


Table 2. Continued

\begin{tabular}{|c|c|c|c|c|c|}
\hline $\begin{array}{l}\text { spot } \\
\text { no. }\end{array}$ & protein name & cellular component & molecular function & biological process & $\begin{array}{l}\text { predicted protein } \\
\text { interaction partners }\end{array}$ \\
\hline 20 & $\begin{array}{l}\text { Ribonuclease/ } \\
\text { angiogenin inhibitor } 1 \\
\text { (RINI) }\end{array}$ & $\begin{array}{l}\text {-angiogenin-PRI } \\
\text { complex }\end{array}$ & $\begin{array}{l}\text {-protein binding } \\
\text { •ribonuclease inhibitor } \\
\text { activity }\end{array}$ & $\begin{array}{l}\text { •mRNA catabolic } \\
\text { process } \\
\text { •regulation of } \\
\text { angiogenesis }\end{array}$ & $\begin{array}{l}\text {-TNF- } \alpha \\
\cdot \text { TNF-R1 } \\
\text {-NF-kappa-B-essential } \\
\text { modulator }\end{array}$ \\
\hline 21 & $\begin{array}{l}\text { Tubulin beta } \\
\text { chain (TBB5) }\end{array}$ & •cytoskeleton & $\begin{array}{l}\text {-MHC class I protein } \\
\text { binding }\end{array}$ & $\begin{array}{l}\text { •cell motility } \\
\text {-natural killer cell } \\
\text { mediated } \\
\text { cytotoxicity }\end{array}$ & $\begin{array}{l}\text { •kinesin-like protein } \\
\text { (KIF1A) } \\
\text { •mitogen-activated } \\
\text { protein kinase } 10 \\
\text { •dual specificity protein } \\
\text { kinase TTK }\end{array}$ \\
\hline 22 & $\begin{array}{c}\text { Melanoma-associated } \\
\text { antigen } 4 \text { (MAGA4) }\end{array}$ & •cytoplasm & -protein binding & $\begin{array}{l}\text { •embryonal } \\
\text { development } \\
\text { •tumor } \\
\text { transformation } \\
\text { •tumor progression }\end{array}$ & $\begin{array}{l}\text {-26S proteosome } \\
\text { regulatory subunit p28 } \\
\text {-B melanoma antigen } 3 \\
\text { precursor }\end{array}$ \\
\hline 23 & Annexin A11(ANX11) & $\begin{array}{l}\bullet \text { cytoplasm } \\
\bullet \text { nuclear envelope } \\
\bullet \text { nucleoplasm }\end{array}$ & $\begin{array}{l}\text {-phospholipid binding } \\
\text { •protein binding }\end{array}$ & $\begin{array}{l}\text {-tumor progression } \\
\text { •immune response } \\
\bullet \text { melanoma } \\
\text { progression } \\
\bullet \text { tumor suppression }\end{array}$ & $\begin{array}{l}\text { •cancer/testis antigen } 2 \\
\text {-programmed cell death } \\
\text { protein } 6 \\
\text {-40S ribosomal } \\
\text { protein } 24 \\
\text { •calcyclin } \\
\text {-DNA-directed RNA } \\
\text { polymerase III }\end{array}$ \\
\hline 24 & $\begin{array}{l}\text { Eukaryotic translation } \\
\text { initiation factor } 3 \\
\text { subunit } 2 \text { (IF32) }\end{array}$ & $\begin{array}{l}\bullet \text { eukaryotic } \\
\text { translation } \\
\text { initiation factor } 3 \\
\text { complex }\end{array}$ & $\begin{array}{l}\text { •protein binding } \\
\text { •translation factor } \\
\text { activity } \\
\bullet \text { nucleic acid binding }\end{array}$ & $\begin{array}{l}\text {-regulation of } \\
\text { translational } \\
\text { initiation }\end{array}$ & $\begin{array}{l}\text { •eukaryotic translation } \\
\text { initiation factor } \\
\text { subunits }\end{array}$ \\
\hline 25 & $\begin{array}{l}60 \mathrm{~S} \text { acidic ribosomal } \\
\text { protein P0 (RLA0) }\end{array}$ & $\begin{array}{l}\text { •cytosolic large } \\
\text { ribosomal subunit }\end{array}$ & $\begin{array}{l}\text { - protein binding } \\
\text { - RNA binding } \\
\text { - structural constituent } \\
\text { of ribosome }\end{array}$ & -translation & $\begin{array}{l}\text { •ribosomal proteins } \\
\text { •elongation factor } \\
\text { 1-gamma }\end{array}$ \\
\hline 26 & $\begin{array}{l}\text { Inosine-5'monophosphate } \\
\text { dehydrogenase } 2 \\
\text { (IMPDH2) }\end{array}$ & •cytoplasm & $\begin{array}{l}\text {-IMP dehydrogenase } \\
\text { activity } \\
\text { •protein binding }\end{array}$ & $\begin{array}{l}\text {-rate-limiting } \\
\text { reaction for the } \\
\text { de novo synthesis } \\
\text { of guanine } \\
\text { nucleotides } \\
\text {-transformation and } \\
\text { progression linked } \\
\text { in cancer cells }\end{array}$ & $\begin{array}{l}\text { •inosine } 5 \text { 'monophosphate } \\
\text { dehydrogenase } 1 \\
\text {-GMP synthase } \\
\text {-GMP reductase } 1 \text { and } 2 \\
\text {-AMP deaminase } \\
1 \text { and } 3\end{array}$ \\
\hline 27,28 & $\begin{array}{l}\text { Aldehyde } \\
\text { dehydrogenase 1A3 } \\
\text { (AL1A3) }\end{array}$ & •cytoplasm & $\begin{array}{l}\text {-3-chloroallyl aldehyde } \\
\text { dehydrogenase } \\
\text { activity }\end{array}$ & $\begin{array}{l}\text {-lipid metabolic } \\
\text { process } \\
\text { •alcohol metabolic } \\
\text { process } \\
\text { •endothelial cell } \\
\text { proliferation and } \\
\text { vascular } \\
\text { remodeling }\end{array}$ & $\begin{array}{l}\text {-3-hydroxyisobutyrate } \\
\text { dehydrogenase } \\
\text { •acetyl-coenzyme A } \\
\text { synthetase 2-like }\end{array}$ \\
\hline 29 & $\begin{array}{l}\text { ATP synthase subunit } \\
\text { beta, mitochondrial } \\
\text { precursor (ATPB) }\end{array}$ & $\begin{array}{l}\text { •mitochondrial } \\
\text { proton-transporting } \\
\text { ATP synthase, } \\
\text { catalytic core }\end{array}$ & $\begin{array}{l}\text { •protein binding } \\
\text { •transporter activity }\end{array}$ & $\begin{array}{l}\text { •cellular energy } \\
\text { provision and for } \\
\text { efficient execution } \\
\text { of apoptosis }\end{array}$ & $\begin{array}{l}\text {-ATP synthase isoforms } \\
\text {-NADH-ubiquinone } \\
\text { oxidoreductase }\end{array}$ \\
\hline 30 & $\begin{array}{l}\text { Rab GDP dissociation } \\
\text { inhibitor alpha (GDIA) }\end{array}$ & •cytoplasm & $\begin{array}{l}\text {-GDP-dissociation } \\
\text { inhibitor activity } \\
\text { •protein binding }\end{array}$ & •signal transduction & $\begin{array}{l}\cdot \text { RAB4A } \\
\cdot \text { RAB5A } \\
\cdot \text { RAB2 } \\
\cdot \text { RAB11A } \\
\cdot \text { RAB9A }\end{array}$ \\
\hline
\end{tabular}

The combining pathway databases of BioCarta (http://www.biocarta.com), KEGG (http://www.genome.ad.jp/kegg/pathways.html) and the PubMed literature (http://www.ncbi.nlm.nih.gov/PubMed) were also used to search the correlated regulatory pathways of cellular response.

\section{Results}

2-D PAGE. To investigate the anticancer effect of kojic acid on protein expression pattern of A375 cells, A375 cells were treated with kojic acid for 24, 48 and $72 \mathrm{~h}$, and were analyzed by 2-D PAGE. The 2-D gel images of the control without treatment and the kojic acid treated A375 cells are shown in Figure 1. Most of the proteins located in the $\mathrm{p} I$ ranges of $3.5-5.0$ and $6.5-8.5$ with the molecular weight of more than $25 \mathrm{kDa}$. With the use of PDQuest image analysis software, the numbers of protein spots detected in control and treatment groups were found to be about 540 spots with no significant difference of the mean numbers among groups. Most of the differentially expressed protein spots showed at the high molecular weight area about $45-100 \mathrm{kDa}$, especially at acidic $\mathrm{pH}$ area. In order to study the late-stage of biological effect of kojic acid on protein expression profile in A375 cells, the time point at $72 \mathrm{~h}$ treatment was chosen to quantitate the protein expression changes between control and treatment groups, and the differentially expressed protein spots were used to further identify the proteins. There were 30 differentially expressed protein spots containing 2 upregulated protein spots, in which the threshold of change in expression level was 1.5-fold, and 28 down-regulated protein spots, in which the threshold of change in expression level was 0.9 -fold. In addition, the 3 -D views of 7 interesting proteins, which have the biological functions involved with p53 tumor suppressor protein or involved in tumor biology, 
are shown in Figure 2. These proteins were then selected for validation by Western blot or RT-PCR.

Protein Identification of Differentially Expressed Proteins. With the use of MASCOT protein identification search software for identifying both peptide mass fingerprinting (PMF) and MS/ MS ion mass data, 30 differentially expressed protein spots were successfully identified. A list of identified proteins, Mowse score, apparent and theoretical MW and $\mathrm{p} I$, number of PMF and MS/MS matched sequences, coverage and fold of change in expression level (up- or down-regulation) are shown in Table 1. Most of identified proteins were down-regulated in kojic acid treated A375 cells, when compared to control group. There were many isoforms of 5 heat shock proteins, 2 endoplasmin precursors, 2 protein disulfide isomerases, 6 vimentins and 2 aldehyde dehydrogenases, which possessed about $56.7 \%$ of those proteins and might be caused by post-translational modifications.

In addition, the category classification of differentially expressed proteins in kojic acid treated A375 cells, according to cellular component, molecular function and biological process, and the prediction of protein interaction partners are shown in Table 2 . When considering their subcellular location, the identified proteins were found to be located at different locations in the cell component. The proteins have diverse functions, especially in protein binding, and play key roles in virtually all biological processes, including apoptosis, mammalian cell cycle progression, regulation of angiogenesis, regulation of cell proliferation, regulation of cell differentiation, and immune response. Interestingly, 11 identified proteins (36.7\% of total proteins), containing heat shock proteins (HS90B, GRP75, GRP78, ENPL (x2), HSP7C), T-complex protein 1 subunit epsilon (TCPE), protein disulfide isomerases (PDIA6, PDIA1), nucleolin (NUCL) and annexin A11 (ANX11), functioned as chaperone proteins, which were found in melanosome from stage I to stage IV with different functions.

Validations by Western Blotting and RT-PCR. Among identified proteins, GRP75, VIME and serine/threonine-protein phosphatase 2A (2AAA) were validated by Western blotting, while GRP75, 2AAA, heat shock protein HS90B, endoplasmin precursor (ENPL) and pyruvate kinase isozyme M1/M2 (KPYM) were validated by RT-PCR (Figure 3). The results of protein and gene expression levels of 7 differentially expressed proteins were in agreement with the 2-D PAGE expression data. GRP75, VIME, HS90B and ENPL were down-regulated proteins in kojic acid treated A375 cells, while 2AAA and KPYM were upregulated proteins in kojic acid treated A375 cells.

Correlation of Differentially Expressed Proteins with Tumorigenesis. Combining the protein interaction and pathway databases of STRING, BioCarta, KEGG and the PubMed literatures, we built a hypothetical model of protein interaction network in the regulation of apoptosis in tumerigenesis, in which 14 differentially expressed proteins of ANX11, ENOG, ENPL, GRP75, GRP78, HSC7C, HS90B1, KPYM, MAGA4, NUCL, PDIA6, PDI, RINI and VIME in kojic acid treated A375 cells are correlated in this network (Figure 4). This network can be divided into 4 network groups: stress related proteins, proteins involved in melanogenesis, proteins involved in regulation of apoptosis and proteins involved in energy metabolism. Most proteins were found to interact with the major regulatory proteins, such as p53 tumor suppressor protein, Bcl2 and Raf1, which play important roles in melanogensis and regulation of apoptosis in A375 cells.

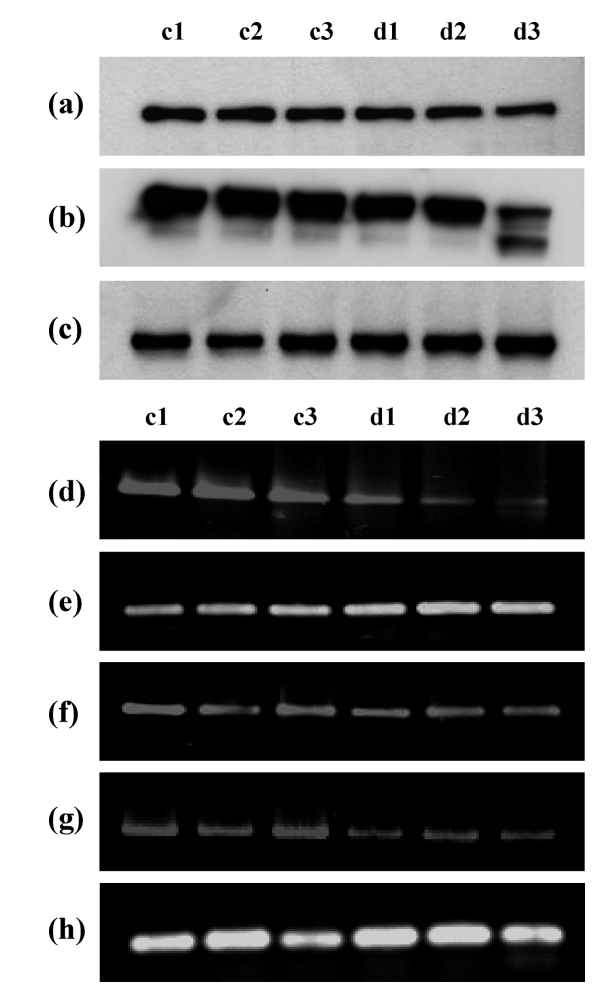

Figure 3. Validations of differentially expressed proteins by Western blot and RT-PCR analyses. For Western blotting: (a) GRP75, (b) VIME, and (c) 2AAA. For RT-PCR: (d) GRP75, (e) 2AAA, (f) HS90B (g) ENPL and (h) KPYM. Labels: c1, c2 and c3 indicate the control groups at 24,48 and $72 \mathrm{~h}$, respectively, and d1, d2 and $d 3$ indicate the treatment groups at 24,48 and $72 \mathrm{~h}$, respectively.

\section{Discussion}

According to our previously study that investigated the toxicogenomic effects of kojic acid on gene expression profiling of A375 cells using microarray, the cell growth inhibition of A375 cells was not strongly affected by all concentrations of kojic acid and a longer treatment time at $72 \mathrm{~h} .{ }^{14}$ There was no morphological change of A375 cells along $72 \mathrm{~h}$ in the presence of $8 \mu \mathrm{g} / \mathrm{mL}$ kojic acid, which was referred as the mild concentration or recommended dosage of kojic acid for human skin safety. The early stage of stimulation effect of kojic acid on gene expression profiling of A375 cells also showed some tumor suppressor genes in A375 cells. Although one gene makes one protein, the modifications of proteins leading to changes in biological and physiological functions may not be caused by gene modification. In order to examine the effects of kojic acid on protein expression level in A375 cells, the same concentration of kojic acid ( $8 \mu \mathrm{g} / \mathrm{mL})$ as in a previous study, which is under the safety recommendation in human skin care products, and various treatment times at 24, 48 and $72 \mathrm{~h}$, were used in this study.

After 2-D PAGE, 30 differentially expressed proteins, showing the significant fold-change of protein expression level at $72 \mathrm{~h}$ treatment, were identified. We used the combined databases to propose the protein interaction network, in which 16 differentially expressed proteins are correlated to the regulation of apoptosis via the major signaling proteins, such as p53, Ras, MEK/ERK, RAF-1 and Bcl-2. Interestingly, 11 chaperone proteins were down-regulated in kojic acid treated A375 cells and were found to be correlated by their interactions to each other 


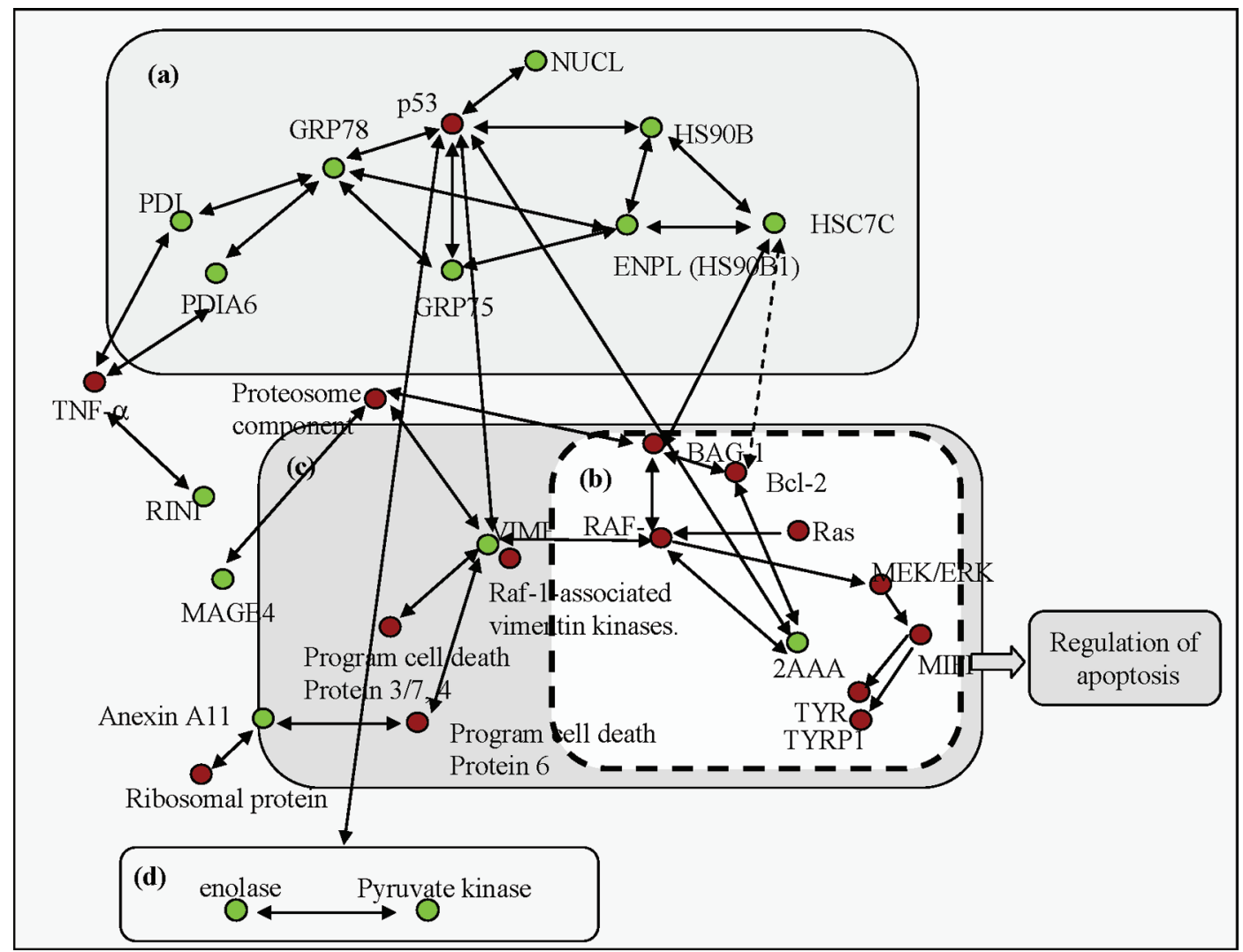

Figure 4. Proposed interaction network of 15 differentially expressed proteins. The interaction network includes both direct and indirect interactions. The green spots indicated proteins that were identified in this study and the red spots indicated proteins that were not identified in this study but were found to interact with the identified proteins. Network groups: (a) stress related proteins, (b) proteins involved in melanogenesis pathway, (c) proteins involved in regulation of apoptosis, and (d) proteins involved in energy metabolism.

(Figure 4a). It is well-known that heat shock proteins are required for cell survival during stress and also have key functions in controlling cellular metabolism. ${ }^{16-18}$ In cancer biology, heat shock proteins were found to express at high levels in facilitate tumor cell growth and survival. ${ }^{19}$ In addition, GRP75, GRP78 and HSP90 have interaction with p53 tumor suppressor. ${ }^{20-23}$ HS90B has a principal role in regulation of mitogenesis and cell cycle progression and could interact with HSP70 or GRP75 to participate in the protein degradation process and protection from programmed cell death. ${ }^{24}$ HSP7C interact with Bcl-2 binding athanogene-1, Bcl-2 binding athanogene-3 and other chaperone proteins, including HS90B and ENPL. ${ }^{25}$ According to our results of down-regulated heat shock proteins in kojic acid treated A375 cells, the cellular stress of the malignant melanoma cells occurred under kojic acid treatment. Kojic acid could suppress the expression of heat shock proteins, which support the tumor growth, and may lead to antiapoptosis effect. On the other hand, since a primary mechanism for heat shock protein's regulation in normal cells involves the tumor repressor p53 and the related protein p63, the down-regulation of heat shock proteins may be involved in the suppression of p53 expression. It has also been reported that p53 and p63 proteins suppressed the transcription of heat shock proteins encoded genes via their binding sites for the transcription factor NF-Y that are presented in their promoters. ${ }^{26,27}$ The suppression of heat shock protein expression by kojic acid may play an important role in the antitumor activity.

The $70 \mathrm{kDa}$ heat shock cognate protein (HSP7C) is a member of HSP70 heat shock proteins. HSC/HSP70 function is regulated by the chaperone Bcl-2-associated gene product-1 (BAG-1), which acts as a coupling factor between HSC/HSP70 and proteasome component. ${ }^{28}$ The BAG-family proteins also contain the BAG-domain that mediates direct interaction with HSP70, ATPase domain and a number of client proteins, including the protein kinase Raf- $1 .{ }^{29-31}$ The Raf- 1 kinase is an important signaling molecule, functioning in the Ras pathway to transmit mitogenic, differentiative, and oncogenic signals to the downstream kinases MEK and ERK. ${ }^{32}$ According to BioCarta pathway of melanogenesis, Raf-1, Ras, MEK and ERK proteins are important regulatory molecules in melanocyte. Moreover, HSP70 also has important role in cotranslational maturation pathway for the human type I membrane glycoprotein tyrosinase, which interacts with calreticulin and $\mathrm{BiP} /$ Grp78 during its ER transit. ${ }^{32,33}$ Thus, the HSP7C linked to the heat shock proteins can interact with the regulatory molecules in the melanogenesis pathway, in which these proteins are upstream regulators of other melanogenic enzymes, including tyrosinase and tyrosinase related protein-1.

The protein phosphatase 2AAA (or PP2A) was found to interact with the hyperphosphorylated/desensitized Raf- $1 .^{34}$ 2AAA is required for the recycling of Raf- 1 to an activationcompetent state and the melanosome aggregation. ${ }^{35}$ It has interaction with the p53 tumor suppressor, Raf-1 and Bcl-2 (Figure 4b). ${ }^{36-38}$ 2AAA is also a major Ser/Thr phosphatase implicated in the regulation of many cellular processes, including many signal transduction pathways and cell cycle progression. ${ }^{39,40}$ In cancer cells, 2AAA has been proposed as a negative regulator of cellular growth and might function as a tumor suppressor. ${ }^{41}$ Confirmation by Western blot analysis 
showed the up-regulated 2AAA in kojic acid treated A375 cells at 48 and $72 \mathrm{~h}$. It is suggested that kojic acid can stimulate the expression of 2AAA, leading to suppression of signaling molecules in melanogenesis.

According to 2-D gel images, 6 isoforms of vimentin were down-regulated in kojic acid-treated A375 cells. It is well-known that vimentin regulates cell migration, membrane trafficking, granular secretion, protein kinase activation and regulation of stress response proteins. ${ }^{42,43}$ The modification of vimentin isoforms might be caused by phosphorylation, which has a central role in regulating the dynamics of vimentin assembly into polymers as well as regulating the connections between intermediated filament (IF) and IF-associated proteins. ${ }^{44,45}$ There are many phosphorylation processes of vimentin; for example, (i) phosphorylation by Raf-1-associated vimentin kinase resulted in the structure of vimentin filaments, ${ }^{46}$ and (ii) phosphorylation by protein kinase C (PKC) provided many isoforms that participate in many signal transduction pathways, such as regulation of organelle movement in melanophores, tyrosine kinase, nucleotide exchange factor, serine/threonine kinase, Raf-1, PKC, cytoskeletal protein actin, proteosome component and HSC70. ${ }^{4-49}$ In addition to phosphorylation, the different spots of vimentin may be due to association with other molecules, such as protein kinase $\mathrm{C}$, integrin or other associated proteins in transduction pathway. Change in vimentin expression level was also generated by stresses, such as heat shock and oxidative stress. ${ }^{50-52}$ The cleavage step of vimentin precedes the recognition of cytoskeletal filaments in apoptosis and programmed cell death mechanisms. ${ }^{53-56}$ Downregulation of vimentin expression inhibits migration and invasion of colon and breast cancer cell lines. ${ }^{56}$ According to Western blot result, the down-regulated vimentin may suppress the tumorigenesis and regulate the apoptosis of kojic acid treated A375 cells. Moreover, the presence of more than one protein bands of vimentin recognized by its monoclonal antibody may be caused by post-translational modifications.

Another protein showing tumor suppression property was pyruvate kinase isoenzyme (KPYM). It is a key sensor for energy consummation and regulation of the glycolytic pathway, in which KPYM links energy rich metabolites from the flow of glucose carbons to nucleic acid. ${ }^{57}$ It was found to interact with gamma enolase (ENOG) (Figure $4 \mathrm{~d}$ ). In yeast cells, the overexpression of pyruvate kinases leads to an inhibition of cell proliferation by depletion of glycolytic phosphometabolites. ${ }^{58}$ Likewise, the pyruvate kinases in eukaryotic cells are involved in fundamental processes, such as cell proliferation, tumor formation and apoptosis. ${ }^{59-61}$ The energy that is used by cancer cells is derived preferentially from glycolysis, in which p53 was found to modulate the balance between the utilization of respiratory and glycolytic pathway. ${ }^{62,63}$ According to our results of 2-D PAGE and Western blot data, the up-regulated KPYM in kojic acid treated A375 cells may play an important role in the suppression of tumor growth and metastasis.

In summary, we identified a number of differentially expressed proteins in kojic acid treated A375 cells. Most of these proteins were the key factor involved in a wide variety of cellular processes, including cell proliferation, regulation of gene expression, signaling, chromatin and cytoskeleton organization. Interestingly, our proposed interaction network revealed the correlated proteins with the regulation of apoptosis, which may lead to suppress the melanogenesis and tumorigenesis of cancer cells. Moreover, these proteins may be the useful biomarkers for further uses in diagnostic and therapeutic applications of skin cancer. However, further functional study of these proteins may lead to better understanding of the pathogenic mechanisms and cellular response to kojic acid treatment.

Acknowledgment. This study was supported by a grant from the Chung Shan Medical University (CSMU 96-OM-B-045) and the Thematic Project in The Life Science, Academia Sinica (94C008-2).

Supporting Information Available: Table of PMF and MS/MS matched peptide sequences of identified proteins. This material is available free of charge via the Internet at http:// pubs.acs.org.

\section{References}

(1) Kwak, M. Y.; Rhee, J. S. Cultivation characteristics of immobilized Aspergillus oryzae for kojic acid production. Biotechnol. Bioeng. 1992, 39, 903-906.

(2) Burdock, G. A.; Soni, M. G.; Carabin, I. G. Evaluation of health aspects of kojic acid in food. Regul. Toxicol. Pharmacol. 2001, 33, 80-101.

(3) Masse, M. O.; Duvallet, V.; Borremans, M.; Goeyens, L. Identification and quantitative analysis of kojic acid and arbutine in skinwhitening cosmetics. Int. J. Cosmetic Sci. 2001, 23, 219-232.

(4) Ohyama, Y. Melanogenesis-inhibitory effect of kojic acid and its action mechanism. Fragrance J. 1990, 6, 53-58.

(5) Shibuya, T.; Murota, T.; Sakamoto, K.; Iwahara, S.; Ikeno, M. Mutagenicity and dominant lethal test of kojic acid. J. Toxicol. Sci. 1982, 7, 255-262.

(6) Wei, C. I.; Huang, T. S.; Fernando, S. I.; Chung, K. T. Mutagenicity studies of kojic acid. Toxicol. Lett. 1991, 59, 213-220.

(7) Lee, Y. S.; Wei, C. I. Chromosomal aberrations in Chinese hamster ovary cells induced by kojic acid. J. Korean Soc. Food Nutr. 1992, $21,454-459$.

(8) Fujimoto, N.; Watanabe, H.; Nakatani, T.; Roy, G.; Ito, A. Induction of thyroid tumours in $(\mathrm{C} 57 \mathrm{BL} / 6 \mathrm{~N} \times \mathrm{C} 3 \mathrm{H} / \mathrm{N}) \mathrm{F} 1$ mice by oral administration of kojic acid. Food Chem. Toxicol. 1998, 36, 697-703.

(9) Tamura, T.; Mitsumori, K.; Onodera, H.; Takahashi, K.; Funakoshi, T.; Yasuhara, K.; Takegawa, K.; Takagi, H.; Hirose, M. The course observation of thyroid proliferative lesions and serum levels of related hormones in rats treated with kojic acid after DHPN initiation. J. Toxicol. Sci. 1999, 24, 145-155.

(10) Higa, Y.; Kawabe, M.; Nabae, K.; Toda, Y.; Kitamoto, S.; Hara, T.; Tanaka, N.; Kariya, K.; Takahashi, M. Kojic acid -absence of tumorinitiating activity in rat liver, and of carcinogenic and photogenotoxic potential in mouse skin. J. Toxicol. Sci. 2007, 32, 143159.

(11) Tamura, T.; Mitsumori, K.; Totsuka, Y.; Wakabayashi, K.; Kido, R.; Kasai, H.; Nasu, M.; Hirose, M. Absence of in vivo genotoxic potential and tumor initiation activity of kojic acid in the rat thyroid. Toxicology 2006, 222, 213-224.

(12) Nakagawa, M.; Kawai, K.; Kawai, K. Contact allergy to kojic acid in skin care products. Contact Dermatitis 1995, 32, 9-13.

(13) Nohynek, G. J.; Kirkland, D.; Marzin, D.; Toutain, H.; LeclercRibaud, C.; Jinnai, H. An assessment of the genotoxicity and human health risk of topical use of kojic acid [5-hydroxy-2(hydroxymethyl)-4H-pyran-4-one]. Food Chem. Toxicol. 2004, 42, 93-105.

(14) Cheng, S. L.; Huang, L. R.; Sheu, J. N.; Chen, S. T.; Sinchaikul, S.; Tsay, G. J. Toxicogenomics of kojic acid on gene expression profiling of a 375 human malignant melanoma cells. Biol. Pharm. Bull. 2006, 29, 655-669.

(15) Tantipaiboonwong, P.; Sinchaikul, S.; Sriyam, S.; Phutrakul, S.; Chen, S. T. Different techniques for urinary protein analysis of normal and lung cancer patients. Proteomics 2005, 5, 1140-1149.

(16) Lindquist, S.; Craig, E. A. The heat shock proteins. Anuu. Rev. Genet. 1998, 22, 631-637.

(17) Beere, H. M. The stress of dying: the role of heat shock proteins in the regulation of apoptosis. J. Cell Sci. 2004, 117, 2641-2651.

(18) Pratt, W. B.; Toft, D. O. Regulation of signaling protein function and trafficking by the hsp90/hsp70-based chaperone machinery. Exp. Biol. Med. 2003, 228, 111-133.

(19) Ciocca, E. R.; Calderwood, S. K. Heat shock proteins in cancer: diagnostic, prognostic, predictive, and treatment implications. Cell Stress Chaperones 2005, 10, 86-103. 
(20) Muller, L.; Schaupp, A.; Walerych, D.; Wegele, H.; Buchner, J. Hsp90 regulates the activity of wild type p53 under physiological and elevated temperatures. J. Biol. Chem. 2004, 279, 48846-48854.

(21) Wadhwa, R.; Yaguchi, T.; Hasan, M. K.; Mitsui, Y.; Reddel, R. R.; Kaul, S. C. Hsp70 family member, mot-2/mthsp70/GRP75, binds to the cytoplasmic sequestration domain of the p53 protein. Exp. Cell Res. 2002, 274, 246-253.

(22) Muller, L.; Schaupp, A.; Walerych, D.; Wegele, H.; Buchner, J. Hsp90 regulates the activity of wild type p53 under physiological and elevated temperatures. J. Biol. Chem. 2004, 279, 48846-48854.

(23) Wang, C.; Chen, J. Phosphorylation and hsp90 binding mediate heat shock stabilization of p53. J. Biol. Chem. 2003, 278, 20662071.

(24) Falsone, S. F.; Gesslbauer, B.; Rek, A.; Kungl, A. J. A proteomic approach towards the Hsp90-dependent ubiquitinylated proteome. Proteomics 2007, 7, 2375-2383.

(25) D'Souza, S. M.; Brown, I. R. Constitute expression of heat shock protein Hsp90, Hsc70, Hsp70 and Hsp60 in neural and non-neural tissues of the rat during postnatal development. Cell Stress Chaperones 1998, 3, 188-199.

(26) Wu, G.; Osada, M.; Guo, Z.; Fomenkov, A.; Begum, S.; Zhao, M.; Upadhyay, S.; Xing, M.; Wu, F.; Moon, C.; Westra, W. H.; Koch, W. M.; Mantovani, R.; Califano, J. A.; Ratovitski, E.; Sidransky, D.; Trink, B. DNp63alpha up-regulates the Hsp70 gene in human cancer. Cancer Res $>$ 2005, 65, 758-766.

(27) Taira, T.; Sawai, M.; Ikeda, M.; Tamai, K.; Iguchi-Ariga, S. M.; Ariga, $\mathrm{H}$. Cell cycle-dependent switch of up-and downregulation of human hsp70 gene expression by interaction between c-Myc and CBF/NF-Y. J. Biol. Chem. 1999, 274, 24270-24279.

(28) Luders, J.; Demand, J.; Hohfeld, J. The ubiquitin-regulated BAG-1 provides a link between the molecular chaperones Hsc70/Hsp70 and the proteosome. J. Biol. Chem. 2000, 275, 4613-4617.

(29) Takayama, S.; Bimston, D. N.; Matsuzawa, S.; Freeman, B. C.; AimeSempe, C.; Xie, Z.; Morimoto, R. I.; Reed, J. C. BAG-1 modulates the chaperone activity of Hsp70/Hsc70. EMBO J. 1997, 16, 48874896.

(30) Zeiner, M.; Gebauer, M.; Gehring, U. Mammalian protein RAP46: an interaction partner and modulator of $70 \mathrm{kDa}$ heat shock proteins. $E M B O J .1997,16,5483-5490$.

(31) Wang, H. G.; Takayama, S.; Rapp, U. R.; Reed, J. C. Bcl-2 interacting protein BAG-1, binds to and activates the kinase Raf-1. Proc. Natl. Acad. Sci. U.S.A. 1996, 93, 7063-7068.

(32) Wang, N.; Daniels, R.; Hebert, D. N. The cotranslational maturation of the type I membrane glycoprotein tyrosinase: The heat shock protein 70 system hands off to the lectin-based chaperone system. Mol. Biol. Cell 2005, 16, 3740-3752.

(33) Popescu, C. I.; Paduraru, C.; Dwek, R. A.; Petrescu, S. M. Soluble tyrosinase is an endoplasmic reticulum (ER)-associated degradation substrate retained in the ER by calreticulin and BiP/GRP78 and not calnexin. J. Biol. Chem. 2005, 280, 13833-13840.

(34) Dougherty, M. K.; Muller, J.; Ritt, D. A.; Zhou, M.; Zhou, X. Z.; Copeland, T. D.; Conrads, T. P.; Veenstra, T. D.; Lu, K. P.; Morrison, D. K. Regulation of Raf-1 by direct feedback phosphorylation. Mol. Cell 2005, 17, 215-224.

(35) Reilein, A. R.; Tint, I. S.; Peunova, N. I.; Enikolopov, G. N.; Gelfand, V. I. Regulation of organelle movement in melanophores by protein kinase $A(\mathrm{PKA})$, protein kinase $\mathrm{C}(\mathrm{PKC})$, and protein phosphatase 2A (PP2A). J. Cell Biol. 1998, 142, 803-813.

(36) Kimura, S. H.; Nojima, H. Cyclin G1 associates with MDM2 and regulates accumulation and degradation of p53 protein. Genes Cells 2002, 7, 869-880.

(37) Okamoto, K.; Li, H.; Jensen, M. R.; Zhang, T.; Taya, Y.; Thorgeirsson, S. S.; Prives, C. Cyclin G recruits PP2A to dephosphorylate Mdm2. Mol. Cell 2002, 9, 761-771.

(38) Muzio, G.; Maggiora, M.; Oraldi, M.; Trombetta, A.; Canuto, R. A. PPAR alpha and PP2A are involved in the proapoptotic effect of conjugated linoleic acid on human hepatoma cell line SK-HEP-1. Int. J. Cancer. 2007, 121, 2395-2401.

(39) Janssens, V.; Goris, J. Protein phosphatase 2A: a highly regulated family of serine/threonine phosphatases implicated in cell growth and signalling. Biochem. J. 2001, 353, 417-439.

(40) Virshup, D. M. Protein phosphatase 2A: a panoply of enzymes. Curr. Opin. Cell Biol. 2000, 12, 180-185.

(41) Schonthal, A. H. Role of serine/threonine protein phosphatase 2A in cancer. Cancer Letter 2001, 170, 1-13.

(42) Wang, N.; Stamenovic, D. Mechanics of vimentin intermediate filaments. J. Muscle Res. Cell Motil. 2002, 23, 535-540.
(43) Benitez-King, G. PKC activation by melatonin modulates vimentin intermediate filament organization in N1E-115 cells. J. Pineal Res. 2000, 29, 8-14.

(44) Inagaki, M.; Inagaki, N.; Takahashi, T.; Takai, Y. Phosphorylationdependent control of structures of intermediate filaments: a novel approach using site- and phosphorylation state-specific antibodies. J. Biochem. 1997, 121, 407-414.

(45) Ku, N. O.; Liao, J.; Omary, M. B. Phosphorylation of human keratin 18 serine 33 regulates binding to $14-3-3$ proteins. EMBO J. 1998, $17,1892-1906$

(46) Janosch, P.; Kieser, A.; Eulitz, M.; Lovric, J.; Sauer, G.; Reichert, M.; Gounari, F.; Büscher, D.; Baccarini, M.; Mischak, H.; Kolch, W. The Raf-1 kinase associates with vimentin kinases and regulates the structure of vimentin filaments. FASEB J. 2000, 14, 2008-2021.

(47) Ivaska, J.; Vuoriluoto, K.; Huovinen, T.; Izawa, I.; Inagaki, M.; Parker, P. J. PKC $\varepsilon$-mediated phosphorylation of vimentin controls integrin recycling and motility. EMBO J. 2005, 24, 3834-3845.

(48) Szalay, J.; Bruno, P.; Bhati, R.; Adjodha, J.; Schueler, D.; Summerville, V.; Vazeos, R. Associations of PKC isoforms with the cytoskeleton of B16F10 melanoma cells. J. Histochem. Cytochem. 2001, 49, 49-65.

(49) Yanagida, M.; Miura, Y.; Yagasaki, K.; Taoka, M.; Isobe, T.; Takahashi, N. Matrix assisted laser desorption/ionization-time of flight-mass spectrometry analysis of proteins detected by antiphosphotyrosine antibody on two-dimensional-gels of fibroblast cell lysates after tumor necrosis factor- $\alpha$ stimulation. Electrophoresis 2000, 21, 1890-1898.

(50) Welch, W. J.; Suhan, J. P. Morphological study of the mammalian stress response: characterization of changes in cytoplasmic organelles, cytoskeleton, and nucleoli, and appearance of intranuclear Actin filaments in rat fibroblasts after heat-shock treatment. J. Cell Biol. 1985, 101, 1198-1211.

(51) Choi, J.; Conrad, C. C.; Dai, R.; Malakowsky, C. A.; Talent, J. M.; Carroll, C. A.; Weintraub, S. T.; Gracy, R. W. Vitamin E prevents oxidation of antiapoptotic proteins in neuronal cells. Proteomics 2003, 3, 73-77.

(52) Paron, I.; D'Elia, A.; D'Ambrosio, C.; Scaloni, A.; D'Aurizio, F.; Prescott, A.; Damante, G.; Tell, G. A proteomic approach to identify early molecular targets of oxidative stress in human epithelial lens cells. Biochem. J. 2004, 378, 929-937.

(53) Byun, Y.; Chen, F.; Chang, R.; Trivedi, M.; Green, K. J.; Cryns, V. L. Caspase cleavage of vimentin disrupts intermediate filaments and promotes apoptosis. Cell Death Differ. 2001, 8, 443-450.

(54) Muller, K.; Dulku, S.; Hardwick, S. J.; Skepper, J. N.; Mitchinson, M. J. Changes in vimentin in human macrophages during apoptosis induced by oxidised low density lipoprotein. Atherosclerosis 2001, 156, 133-144.

(55) Yang, X.; Wang, J.; Liu, C.; Grizzle, W. E.; Yu, S.; Zhang, S.; Barnes, S.; Koopman, W. J.; Mountz, J. D.; Kimberly, R. P.; Zhang, H. G. Cleavage of p53-vimentin complex enhances tumor necrosis factor-related apoptosis-inducing ligand-mediated apoptosis of rheumatoid arthritis synovial fibroblasts; cell injury, repair, aging and apoptosis. Am. J. Pathol. 2005, 167, 705-719.

(56) Sheikh, M. S.; Fornace, A. J., Jr. Death and decoy receptors and p53-mediated apoptosis. Leukemia 2000, 14, 1509-1513.

(57) Ginisty, H.; Sicard, H.; Roger, B.; Bouvet, P. Structure and functions of nucleolin. J. Cell Sci. 1999, 112, 761-772.

(58) Grinstein, E.; Wernet, P.; Snijders, P. J.; Rosl, F.; Weinert, I.; Jia, W.; Kraft, R.; Schewe, C.; Schwabe, M.; Hauptmann, S.; Dietel, M.; Meijer, C. J.; Royer, H. D. Nucleolin as activator of human papillomavirus type 18 oncogene transcription in cervical cancer. J. Exp. Med. 2002, 196, 1067-1078.

(59) Ying, G. G.; Proost, P.; van Damme, J.; Bruschi, M.; Introna, M.; Golay, J. Nucleolin, a novel partner for the Myb transcription factor family that regulates their activity. J. Biol. Chem. 2000, 275, 41524158.

(60) Daniely, Y.; Dimitrova, D. D.; Borowiec, J. A. Stress-dependent nucleolin mobilization mediated by p53-nucleolin complex formation. Mol. Cell. Biol. 2002, 22, 6014-6022.

(61) Wang, Y.; Guan, J.; Wang, H.; Leeper, D.; Iliakis, G. Regulation of DNA replication after heat shock by replication protein A-nucleolin interactions. J. Biol. Chem. 2001, 276, 20579-20588.

(62) Atkinson, D. E.; Walton, G. M. Adenosine triphosphate conservation in metabolic regulation. J. Biol. Chem. 1967, 10, 3239-3241.

(63) Brazill, D. T.; Thormer, J.; Martin, S. Mck1, a member of the glycogen synthase kinase 3 family of protein kinase, is a negative regulator of pyruvate kinase in the yeast Saccharomyces cerevisiae. J. Bacteriol. 1997, 179, 4415-4418.

PR7008737 